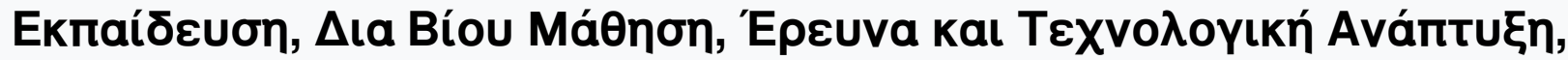 Katvotopía kal Oıкоvopía
}

Tóp. 1 (2016)

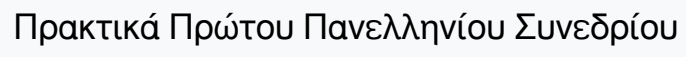

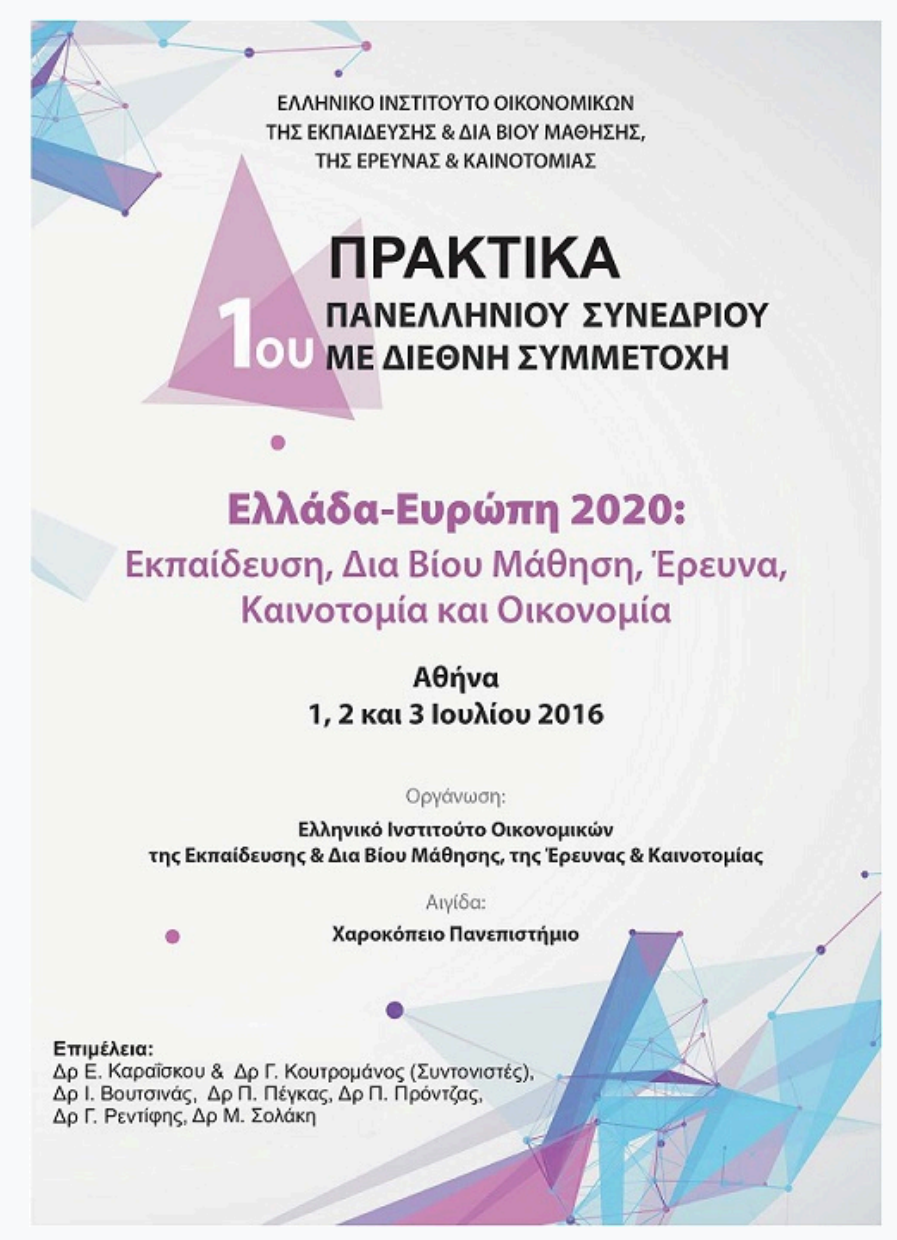
Management Performance Evaluation - The Case of
Social Solidarity Hospitals

Richard-Nicolas LACROIX, John Filos

doi: $\underline{10.12681 / \text { elrie. } 818}$ 


\title{
Management Performance Evaluation - The Case of Social Solidarity Hospitals
}

\author{
Richard-Nicolas LACROIX ${ }^{1}$, John Filos ${ }^{2}$ \\ ricniclac@gmail.com,filosj@panteion.gr \\ ${ }^{I}$ PhD, National School of Public Administration, Areos 7, 17562 Palaio- Faliro, Greece,(Professor of \\ Business, International Program at Athens Metropolitan College for Queen Margaret University, \\ Edinburg \& University of East London, UK). \\ ${ }^{2}$ CIA, CFE, PhD, Associate Professor Department of Public Administration, Panteion University, \\ Greece
}

\begin{abstract}
Hospitals performance can be evaluated at Board, Management and Employee Levels. "For profit focused" privately operated hospitals tend to be budget efficient; yet, their refusal to treat noninsured/non-paying patients while maximizing profit versus the sufficient essential make them clinically less efficient. Bureaucratic Public Hospitals, while efficient on the treatment side, are a blank check in the budget balancing area. Studies suggest: The Social Solidarity Hospitals, while funded by capital earned from profit making enterprises and donations and volunteers work, seem to offer better value for money than alternatives. Information showing how decisions are made and with which criteria boards are being evaluated, is a gap in current academic literature. Further research is needed on Hospitals board performance evaluation criteria and KPIs. The SMMM tool based on the Data Envelopment Methodology is used to evaluate board performance and examples of social solidarity hospitals good practices from Greece are presented.
\end{abstract}

Keywords: Performance Management Evaluation, Social Solidarity Hospitals, SMMM tool

\section{Introduction}

While the medical field is full of efficient doctors, nurses, support personnel and administrators, many of which are customer focused and work ethically. Unfortunately the last decade has seen an increase of newspaper and trade articles discussing pending and ongoing lawsuits and scandals pointing to Hospital mismanagement and shortcomings. We may ask how in spite of all the best practices information availability and specialized training we still manage to have Hospital managers get caught in scandals (for instance of mismanagement of hospital supplies or overcharging of medical insurance charges). This complex subject can in practice be evaluated by shareholders by monitoring one or more of these three levels: Board, Management and Employee Levels.

Historically, "For profit focused" privately operated hospitals tend to be budget efficient; yet, their refusal to treat non-insured/non-paying patients while maximizing profit versus the sufficient essential make them clinically less efficient. Bureaucratic 
Public Hospitals while efficient on the treatment side are a blank check in the budget balancing area. The quality and the value of health services for the money spent they provide is, in most cases, not proportional to the investment (waste of resources is common practice). Recent Studies suggest that the Social Solidarity Hospitals, while funded by capital earned from profit making enterprises and donations and volunteers work, (with limited range of offerings) seem to offer better value for money than alternatives. Besides financial criteria, non-financial could prove equally important to the three criteria used for financial performance (e.g. community offering, value for money invested, value for patients, etc.).

In this paper we discuss how the performance of Private versus Public versus Social Solidarity Hospitals can be measured. In the next section, reference will be made to some of the more significant literature search findings and existing gaps not adequately covered by recent studies and journal or conference publications. Further in the article, we will attempt to suggest recommendations from the World Health Organization (WHO) that are considered best of class practices for hospital management. The SMMM tool, based on the Data Envelopment Methodology, will also be examined as a possible means to evaluate hospital board performance. Illustrative examples of success stories from Greece will be presented together with a current conclusion on the current state of affairs and future perspectives worthy to be pursued by Hospital Boards in the coming years.

\section{Measuring Hospital performance}

Measuring Hospital Performance requires the commitment and involvement of the Board of Directors (BOD). According to the American Governance Web site (www.americangovernance.com/checklist) which provides scorecards and checklist, there are six dimensions by which a hospital board can be measured (Mission, Allocation, Culture, Strategy, Performance and Leadership). In the Performance dimension component, the Board has an essential role in overseeing that the strategies and policies set by executive management officers gets implemented in accordance with some agreed quality plan of action and within specific deadlines. The measurement of the efficiency of the implementation of that quality plan consists in checking if specific achievements have been accomplished at specific deadlines as originally scheduled and observing and explaining any deviations that occurred in that quality plan. The plan can be monitored at best by an audit process conducted by certified public accountants in conjunction with management consultants, to confirm the Hospital follows a policy of transparency which can be considered valid by all internal and external stakeholders. In that respect let us observe the six sample evaluation questions suggested on the American Governance Web site: (Their intent is helping auditors determine the current level of maturity of the measured Hospital in comparison to others which might be considered leaders in that field) "1) Do we have a Quality Improvement Plan (QIP) that identifies specific Gaps in performance and targets improvement by certain dates? (Yes/No)

2) Do we have the right measures to evaluate our quality performance? (Yes/No)

3) Do we have the right tools to monitor our progress? (Yes/No)

4) Are we benchmarking against high-Performing organizations and/or the theoretical limit? (Yes/No)

5) Do we have the right Board processes in place for reviewing and evaluating quality performance? (Yes/No) 
6) Do we share our performance with our patients, employees and the community? (Yes/No)"

With respect to that last of the suggested questions, good practice around the world has benefited from feedback of patients. One very successful program that did just that, was deployed over the last five years in western London and ran in roughly half the hospitals of the UK under the name "Friends \& Family Test" (see Figure 1)
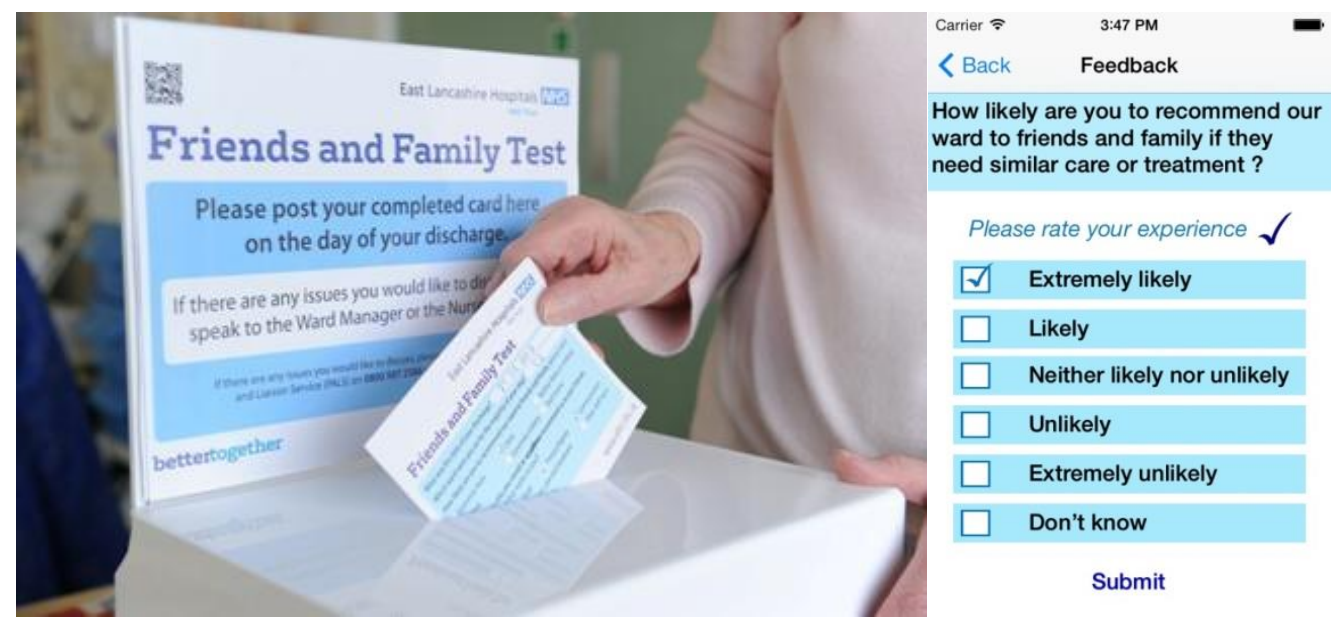

Figure 1: Friends and Family Test: Capturing Patient Feedback. (UK 2014).

One of the better attributes of that program was that patients were asked to rate the value for money of their hospital experience and sharing that experience with other patients over the internet (Figure 2) thus giving the whole health system reputation reasons to improve.

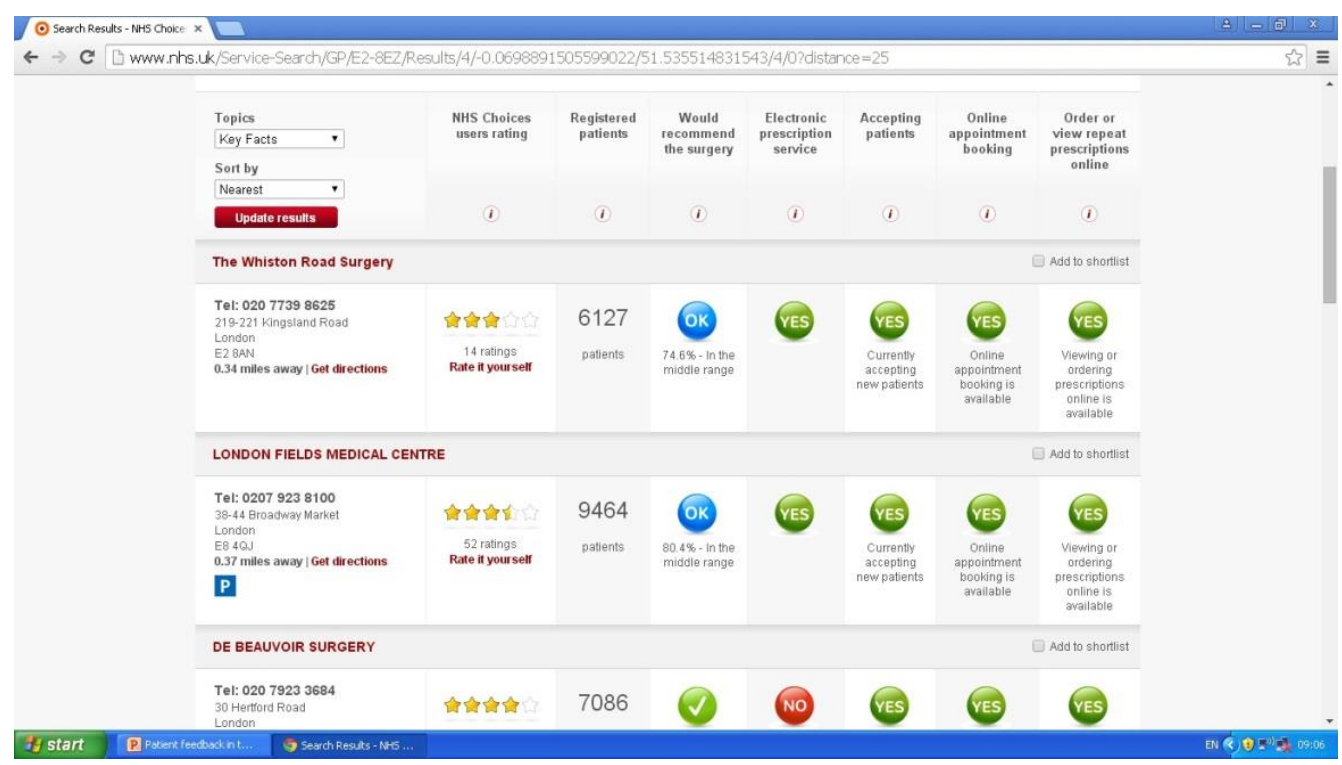

Figure 2: Friends and Family Test - Grading the Patient experience with stars and leaving comments for other patients to see on the internet. (UK 2014)

This Feedback is very valuable for shareholders to measure the patients and reputation of the hospital in addition to the financial indicators and, in an ideal world, should be 
tied to the bonuses perceived by board members. In the next section we examine some of the most significant literature publications on hospital performance and current gaps for future resolution.

\section{Indicative Literature \& Gap in existing studies for future research}

In this section, the indicative literature review focuses on five more significant references. We then expose the Gap in the aforementioned studies for future research.

1) The Social and Cultural Planning Office, 2004.

This report demonstrates convincingly that there is no one-to-one relationship between resources made available to sectors like health care and education and the overall performance of the public health sector (as stated on p25 in the summary). High health spending provides no guarantee whatsoever of good system performance. This is best illustrated by the US and Germany. The same can also be said of the privatization of health care.

Analysis: Some of the main reasons can be attributed to factors such as: 1) Demographics, 2) Wage Levels (If wage levels in the labor intensive production of public services are relatively low, taxpayers get more and arguably better services), 3) large bureaucracies often have trouble handling an outpour of new money, 4) Policies aimed to stimulate economic growth and policies to further equity are not mutually exclusive. The hypothesized negative correlation between the level of government spending and taxation vs., economic growth is much weaker than is often maintained.

2) Chien-Ming Chen \& Magali Delmas (UCLA), Measuring Corporate Social Performance: An Efficiency Perspective, (2010)

This article discusses the measurement of the social performance of firms' operations using the Data Envelopment Analysis (DEA), a mathematical programming method for evaluating the relative efficiencies of firms (Charnes et al. 1978, Cook and Zhu 2006) that does not require a priori weights to aggregate different CSP dimensions.

Analysis: DEA computes an efficient frontier that represents the best performers in a peer group. The DEA Social Performance score represents the distance of a firm to the efficient frontier and the extent to which a firm can reduce its current concerns, given its strengths relative to those of the best performers. The SMMM tool suggested later in this presentation for evaluating the performance of hospital management is based on this methodology.

3) Peter Miller (Southern Cross University), Board performance evaluation: case study of a private hospital in Australia (2009) (Review of International Comparative Management Volume 10, Issue 1, March 2009 p.140).

The central theme in much of the research relates to whether it is appropriate for nonprofit organizations to converge or diverge with the corporate governance practices of for profit organizations.

Analysis: In arguing this case, they evaluate both stakeholder and stewardship approaches to corporate governance in the non-profit social enterprise sector (a key difference between for profit and non-profit organizations identified by Steane and Christie (2001, p. 56) where 'non-profit Boards can mimic some aspects of a 
shareholder approach to governance' but, in fact, have priorities and activities that indicate 'a stakeholder approach to governance'.

1- The primary purpose of a performance evaluation is to achieve continual improvement in the governance of the Board.

2- Any relevant evaluation can only be made against criteria established by the Board as to what constituted responsible governance.

3- To improve performance, evaluation must be frequent and continuous.

4) The European Observatory on Health Systems, Investing in hospitals of the future, WHO (2009).

This rapport discusses:

1) The changing context of capital investment

2) Influencing capital investment

3) Economic aspects of capital investment

4) Translating hospital services into capital asset solutions

5) Conclusions and critical success factors

Analysis: There is more to performance than spending, the greater budget does not guarantee success, several counter examples demonstrate that much spending usually leads to waste.

5) Uwe E. Reinhardt, "The Economics of For-Profit and Not-For-Profit Hospitals, Nonprofit hospitals owe society community benefits in exchange for their tax exemption, but what is a fair amount?" (2010|), HEALTH AFFAIRS - Volume 19, Number 6.

This rapport discusses the main findings and comparison of differentiators between legal and financial aspects of these hospitals in Europe, the US and some other countries outside Europe. It mentions best practices and several success stories for not for profit hospitals.

Analysis: Several investments in not for profit hospitals are demonstrated to be worthwhile (remember that If Net Present Value (NPV) $>0$ or (Internal Rate of Return (IRR) > rate, this implies $=>$ A Good Investment as shown in the three exhibits of Figure 3 below for some non-profit hospitals.

\begin{tabular}{|c|c|c|}
\hline & Netcperatingsesh flow & \\
\hline Year & ForproffithCi's perspective & Nonprofit CMnc's perspective \\
\hline $\begin{array}{l}0 \\
1 \\
2 \\
3 \\
\end{array}$ & $\begin{array}{r}-\$ 4,000,000 \\
910,000 \\
1,078,000 \\
899,300\end{array}$ & $\begin{array}{r}-\$ 4,000,000 \\
970,000 \\
970,000 \\
970,000 \\
\end{array}$ \\
\hline $\begin{array}{l}4 \\
5 \\
6 \\
\end{array}$ & $\begin{array}{l}791,500 \\
791,500 \\
711,700\end{array}$ & $\begin{array}{l}970,000 \\
970,000 \\
970,000\end{array}$ \\
\hline $\begin{array}{l}\text { Net present value (NPV) } \\
\text { Internal rats of retumn (IRR) }\end{array}$ & $\begin{array}{r}-\$ 309,463 \\
8.44 \%\end{array}$ & $\begin{array}{r}\$ 495,097 \\
11.90 \% 6\end{array}$ \\
\hline
\end{tabular}

SOURCE: Author's analyst. 


\begin{tabular}{|c|c|c|c|}
\hline \multicolumn{4}{|c|}{$\begin{array}{l}\text { EXHIBIT } 2 \\
\text { Net Present Values (NPVs)At Common Cost-Of-Capltal Rates For Two Hospltals, HCl } \\
\text { And CMC }\end{array}$} \\
\hline $\begin{array}{l}\text { Assumad cost } \\
\text { of finanking }\end{array}$ & $\begin{array}{l}\text { RPV from the forerofit } \\
\text { HCI's perspecthe }\end{array}$ & $\begin{array}{l}\text { PPV from the nonprofit } \\
\text { Cincts perspective }\end{array}$ & $\begin{array}{l}\text { Extra KPYeamed by } \\
\text { the norppofit hosplta }\end{array}$ \\
\hline $\begin{array}{l}8 \text { veroent } \\
9 \text { peroent }\end{array}$ & $\$ 50.538$ & $\$ 484.193$ & $\$ 433.655$ \\
\hline $\begin{array}{l}10 \text { percent } \\
11 \text { percent }\end{array}$ & $\begin{array}{r}-171,493 \\
-275,228\end{array}$ & 224,603 & 396,095 \\
\hline 11 percent & & 103,622 & \\
\hline 12 percent. & $-374,476$ & $-11,935$ & 362,541 \\
\hline 13 percent & $-469,485$ & $-122,377$ & 347,108 \\
\hline 14 percent & $-560,490$ & $-227,993$ & 332,498 \\
\hline 15 percent & $-647,710$ & $-329,052$ & 318,658 \\
\hline \multicolumn{4}{|c|}{ SOURCE:Author's analyak. } \\
\hline \multicolumn{4}{|c|}{$\begin{array}{l}\text { EXHIBIT } 3 \\
\text { Break-Even Prices Per Procedure For Two Hospltals, } \mathrm{HCl} \text { And CMC }\end{array}$} \\
\hline \multicolumn{4}{|c|}{ Breakeaven price } \\
\hline Oost of firsanding & FopprofiteroI & Monproift OMno & HOI as perosnt of OMMO \\
\hline 8 percent & $\$ 695$ & 5666 & $104.4 \%$ \\
\hline 10 percent & 720 & 683 & 105.4 \\
\hline 12 percent & 745 & 701 & 106.3 \\
\hline 14 peroent & 772 & 719 & 107.4 \\
\hline
\end{tabular}

Figure 3: Exhibits 1, 2 and 3 from Uwe E. Reinhardt (2010).

Gap Areas Identified in Literature Search: We identified two gap areas in existing academic literature which includes:

1) A lack of a commonly accepted standard on how Hospital Boards Performance should be evaluated (in practice this rarely happens - strategy should be tied to achievable and measurable objectives and deadlines, bonuses should be tied to achieving these objectives.)

2) Information showing how Hospital Board decisions are made and with what KPIs criteria boards are being evaluated (most hospital boards do not transparently share and publish the measures with which their performance will be evaluated shareholders should demand that these be published and monitored for progress).

\section{Recommendations from the World Health Organization (WHO 2009)}

In order to circumvent some of the more frequent problems with hospital management the WHO developed a task force and published in 2009 what could be called "the Ultimate" Best Practices. These recommendations, while achievable at various degrees, require that hospital boards invest in changing established cultures and changing practices to be more in line with a Total Quality Management process approach to solving business issues. Several years later, some of the better hospitals with regards to being considered leaders around Europe, have implemented many of the recommendations at various degrees, while many other hospitals have not even started.

Let us look at some of these recommendations. Figure 4 (WHO table 1.1) addresses the primary reason why some hospitals never reach their potential because patients forget they are the client who has rights to choose between hospital offerings and the power to express how their tax money is spent for the value received. 
Table 1.1 Potertial charges in the waythat patierts use services

\begin{tabular}{|c|c|}
\hline OId approach & New (idealized) approach \\
\hline $\begin{array}{l}\text { Patients use the systern in a series of } \\
\text { unconnected episodes }\end{array}$ & $\begin{array}{l}\text { Need is anticipated and hospitals and health } \\
\text { systerns develop meshods to manage the } \\
\text { whole pathway of dsease, support patients } \\
\text { in their own home and have electronic } \\
\text { records that help to ensure continuiny of care }\end{array}$ \\
\hline Patients are passive recipients of care & $\begin{array}{l}\text { Patients are irwolved in the management of } \\
\text { their awn care }\end{array}$ \\
\hline $\begin{array}{l}\text { Patients are dealt with in batches and } \\
\text { spend most of their time within the } \\
\text { system waiting - this is because it is } \\
\text { irmportant. to keepp expersive staff and } \\
\text { assets busy }\end{array}$ & $\begin{array}{l}\text { Patients flow through the system with } \\
\text { rrinimal waits. Sweating the assets and } \\
\text { having staff busy is less impoxtant than } \\
\text { achieving a smooth flow through the system }\end{array}$ \\
\hline \multirow[t]{2}{*}{$\begin{array}{l}\text { Patients are treated as though their time } \\
\text { is free and are required to undertake } \\
\text { significant amourts of unpaid work and } \\
\text { movernerits for the corivenience of the } \\
\text { providers }\end{array}$} & $\begin{array}{l}\text { Consurnerism and the increasing tirne } \\
\text { poverty of marty people mean that a } \\
\text { premium wil be places on convenience and } \\
\text { speed }\end{array}$ \\
\hline & $\begin{array}{l}\text { The pressure for efficiency and the rieed to } \\
\text { eliminate uninecessary steps in the process } \\
\text { will also mean that moving information and } \\
\text { staff - rather than patients - becomes a } \\
\text { rnore accepted principle }\end{array}$ \\
\hline $\begin{array}{l}\text { Services are designed around the } \\
\text { historic way providars are structured }\end{array}$ & $\begin{array}{l}\text { Services are designed to meet the } \\
\text { requirmments of patients }\end{array}$ \\
\hline $\begin{array}{l}\text { Patients go to hospital for routine } \\
\text { monitaring }\end{array}$ & $\begin{array}{l}\text { Horne based technology and diagnostic } \\
\text { equipment outside the hospital redure the } \\
\text { use of hospitals }\end{array}$ \\
\hline $\begin{array}{l}\text { Interaction is face to face and on a one- } \\
\text { to-one basis }\end{array}$ & $\begin{array}{l}\text { E-mail and telephorie can be used and } \\
\text { group visits seern to work for some issues }\end{array}$ \\
\hline $\begin{array}{l}\text { Providers deterrime follow-up and re- } \\
\text { referral }\end{array}$ & $\begin{array}{l}\text { Patients can initiate follow-up and have a } \\
\text { right of return or drect access to speciaist } \\
\text { help if they think they need it - even if they } \\
\text { have beern discharged }\end{array}$ \\
\hline $\begin{array}{l}\text { Patients aften die in hospital when they } \\
\text { would have preferred ta die at horne }\end{array}$ & Patients have plans for end-of-Ife care \\
\hline
\end{tabular}

Figure 4: Potential changes to the way Patients Use Services

Source: WHO, Investing in Hospitals of the Future (2009) European Observatory on Health Systems and Policy

The solution does not require a blame on the part of the patients but also a shared responsibility on the side of the care givers of that service which often forget to be patient centric in their culture and their approach to doing business (potential changes in the way hospital staff work) as seen in Figure 5 (WHO table 1.2).

Table 1.2 Ptertia charges to the way stiff work

\begin{tabular}{|c|c|}
\hline Oid approach & New (idealized) approach \\
\hline $\begin{array}{l}\text { See a jurior member of staff who } \\
\text { escalates }\end{array}$ & $\begin{array}{l}\text { See a serict mernber who makes decisions } \\
\text { and delegates - this should reduce the } \\
\text { number of patierts adrnited to hospital and } \\
\text { reduce the length of stay of those that are } \\
\text { adrritted }\end{array}$ \\
\hline See a doctor & See the most appropriate professional \\
\hline Reduce the skill mix to save money & $\begin{array}{l}\text { Increase the skil mix to improve efficiency and } \\
\text { outcomes }\end{array}$ \\
\hline $\begin{array}{l}\text { Stafl develop "work arounds" for } \\
\text { probiems }\end{array}$ & $\begin{array}{l}\text { Staff undertake root cause arialysis to create } \\
\text { sustainable solusions }\end{array}$ \\
\hline $\begin{array}{l}\text { Large amourits of time ate wasted by } \\
\text { poor work process design - salety may } \\
\text { also be compromised }\end{array}$ & $\begin{array}{l}\text { Unnecessary staff movement can be reduced } \\
\text { by the proper design of work processes and } \\
\text { the work ervironment as wel as the use of It } \\
\text { systems }\end{array}$ \\
\hline $\begin{array}{l}\text { Marry services stop at weekends and in } \\
\text { the everings }\end{array}$ & $\begin{array}{l}\text { Specialist consultation, diagnostics and othes } \\
\text { support sevioes are avalable for much longer } \\
\text { than the traditional working week }\end{array}$ \\
\hline $\begin{array}{l}\text { Beds are a matk of prestige and a } \\
\text { source of incorne }\end{array}$ & $\begin{array}{l}\text { Beds are a cost centre and ennergency non- } \\
\text { surgical admissions are seen as a sign of } \\
\text { system failure }\end{array}$ \\
\hline
\end{tabular}

Figure 5: Potential changes to the way hospital Staff work

Source: WHO, Investing in Hospitals of the Future (2009) European Observatory on Health Systems and Policy 
Comparing system descriptors can serve as a guideline with regards to what has worked in the past for various categories of hospitals (private for profit, public nonprofit, social) as seen in Figure 6 below.

\begin{tabular}{|c|c|c|c|c|c|c|}
\hline Dimension & Characteristics & $\begin{array}{l}\text { Northern } \\
\text { Ireland }\end{array}$ & $\begin{array}{l}\text { Nether- } \\
\text { lands }\end{array}$ & England & $\begin{array}{l}\text { Spain } \\
\text { (Nalencla } \\
\text { - Alzira } \\
\text { Model) }\end{array}$ & $\begin{array}{l}\text { Italy } \\
\text { (Tus- } \\
\text { cany) }\end{array}$ \\
\hline \multirow{3}{*}{$\begin{array}{l}\text { Across } \\
\text { systems } \\
\text { Integration }\end{array}$} & $\begin{array}{l}\text { Acute, primary and social } \\
\text { care each operate as stand- } \\
\text { alone systerns }\end{array}$ & & $x$ & $\mathrm{x}$ & & \\
\hline & $\begin{array}{l}\text { Acute and primary care run } \\
\text { as parts of an integated } \\
\text { area-based system, wen } \\
\text { socilal care as a separate } \\
\text { system }\end{array}$ & & & & $\mathrm{x}$ & $\mathrm{x}$ \\
\hline & $\begin{array}{l}\text { Acute, primaty care and } \\
\text { social care operate as parts } \\
\text { of an integrated area-based } \\
\text { system }\end{array}$ & $x$ & & & & \\
\hline \multirow{4}{*}{$\begin{array}{l}\text { Hespital } \\
\text { çoverrances }\end{array}$} & Private profit-making & & & & $x^{\prime}$ & \\
\hline & $\begin{array}{l}\text { Seff-standang non proft: } \\
\text { making, chartin }\end{array}$ & & $\bar{x}$ & & & \\
\hline & $\begin{array}{l}\text { Puxik: intasest company } \\
\text { (Foundason thust) }\end{array}$ & & & $x$ & & $x$ \\
\hline & $\begin{array}{l}\text { Puevicty owned and } \\
\text { managed as part } \alpha \text { an area- } \\
\text { based service structure }\end{array}$ & $x$ & & & & \\
\hline \multirow{5}{*}{$\begin{array}{l}\text { Hespltal } \\
\text { funding } \\
\text { frecurrert } \\
\text { experadture) }\end{array}$} & $\begin{array}{l}\text { Acemity adjusted abocabon } \\
\text { from pubic funds via an } \\
\text { ares bused adminstratve } \\
\text { structure }\end{array}$ & $x$ & & & & \\
\hline & $\begin{array}{l}\text { Poyment by occasion of } \\
\text { strvice trom piovic unds }\end{array}$ & & & $x$ & & $x$ \\
\hline & $\begin{array}{l}\text { Payerent by occasion of } \\
\text { service from inserarce turds }\end{array}$ & & $x$ & & & \\
\hline & Drect paymans from patert & & & & & \\
\hline & (Fee basedf captation & & & & $\mathrm{x}$ & \\
\hline \multirow{4}{*}{$\begin{array}{l}\text { Gerneral } \\
\text { practice } \\
\text { funding }\end{array}$} & $\begin{array}{l}\text { Capilation-based syslem } \\
\text { from public funds }\end{array}$ & $x$ & & $x$ & $x$ & $\mathrm{x}$ \\
\hline & $\begin{array}{l}\text { Payment by occasion of } \\
\text { service from public unds }\end{array}$ & & & & & \\
\hline & $\begin{array}{l}\text { Paymert by occasion of } \\
\text { service fiom insurance tunds }\end{array}$ & & $x$ & & & \\
\hline & Drect payment from pattert & & & & & \\
\hline
\end{tabular}

Figure 6: Descriptors Comparison between 5 different types of European Hospitals

Source: WHO, Investing in Hospitals of the Future (2009) European Observatory on Health Systems and Policy

Success Stories are not limited to the major European countries compared in the previous table. The following two figures present social solidarity hospitals good practices from Greece (Figures 7 Swedish member of the European Parliament Mikael Gustafsson visiting \& 8). 


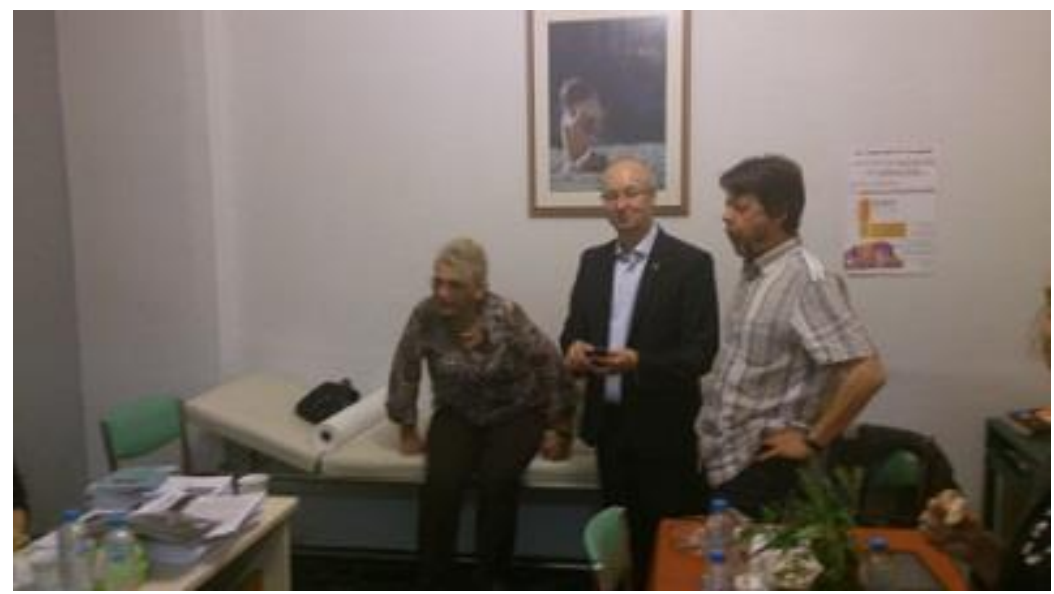

Figure 7: The Social Solidarity clinic of Peristeri (Greece 2013)

Source: https://iatreioallperisteriou.wordpress.com/news-in-english/

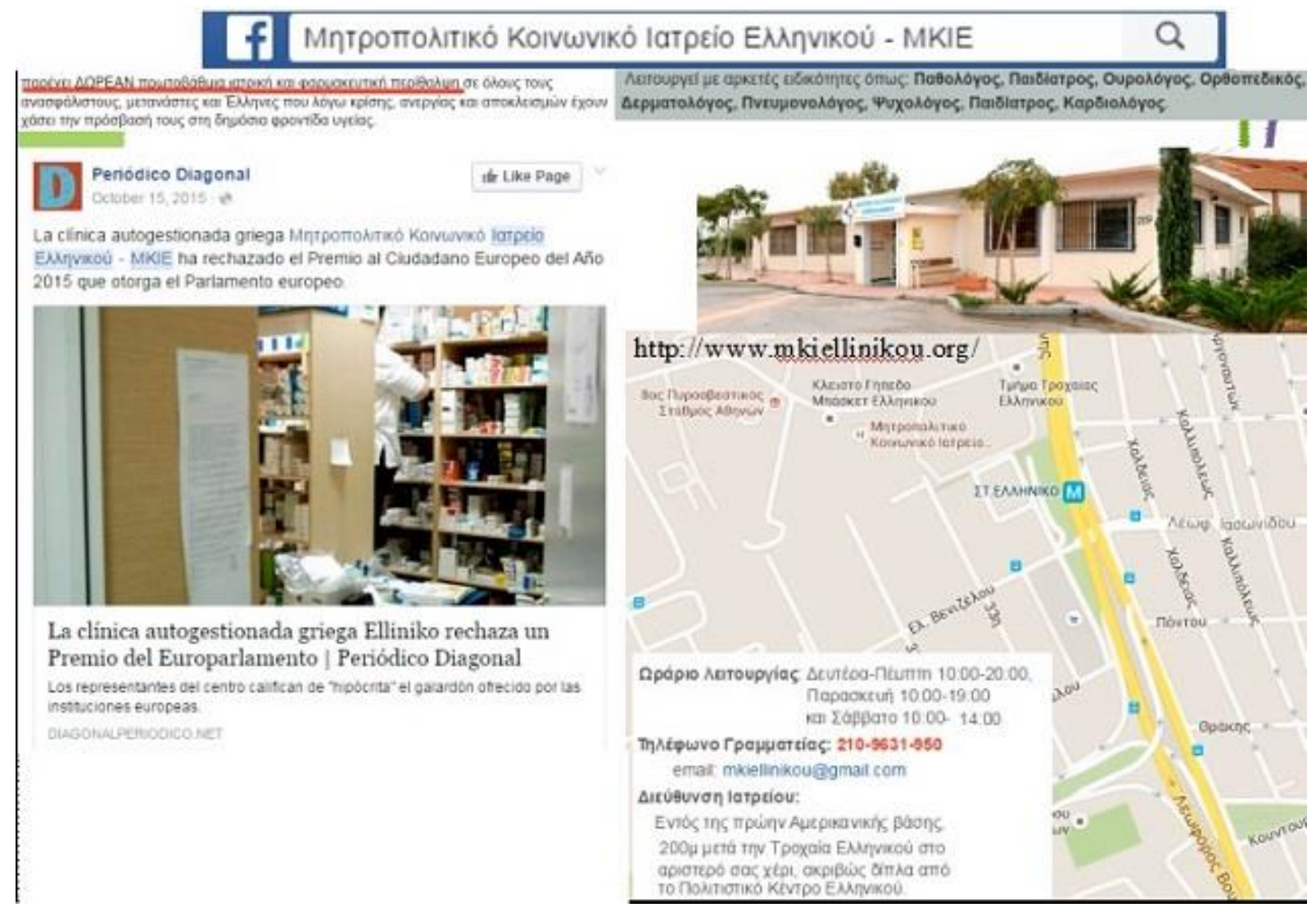

Figure 8: The Social Solidarity clinic of Helliniko (Greece 2015)

Source: www.mkiellinikou.org

\section{Discussion - Why are the WHO Recommendations Rarely Practiced?}

Several Reasons have been advanced by board members and Health professionals that we interviewed: 
1) Assigning Lawyers or Non-Business experienced professionals to the Board as administrators (including Medical doctors) with little MANAGEMENT experience is a recipe for failure.

2) Political Motivated assignments of administrators not based on PERFORMANCE offer no Guarantee especially when MOTIVATION / DEDICATION to the Health Mission is not validated by Patients and Hospital Staff.

3) Applying Best practices involves a commitment to A QUALITY CULTURE and BEING LEGALLY AND FINANCIALLY ACCOUNTABLE.

4) TRANSPARENCY means encouraging being SCRUTINIZED and ACCOUNTABLE by Patients/Investors and the General Public.

5) Applying BEST PRACTICES is a Balancing Act to deliver Value for Investors, Patients, Society (within Budget while increasing throughput and Guaranteeing Quality of Health services FOR ALL).

One Possible Solution: The Trustee Toolbox www.mhhp.com suggests doing the following:

8. Why Should Boards Regularly Do a Self-Assessment? (US Joint Commission on Accreditation of Healthcare Organizations (JCAHO) are required to conduct an annual board self-assessment. JCAHO Standard) LD.4.5 requires hospital leadership to:

9. Set measurable objectives for improving hospital performance;

10. Gather information to assess their effectiveness in improving hospital performance;

11. Use pre-established, objective process criteria to assess their effectiveness in improving hospital performance;

12. Draw conclusions based on their findings and develop and implement improvement in their

13. activities; and

14. Evaluate their performance to support sustained improvement.

15. How should the Assessment be Used to Improve Governing Performance?

16. What are the Costs of Board Under-Performance?

Examples of reports for management to evaluate hospital performance from the Trustee Toolbox can be seen in Figures $9 \& 10$ Below. 
Cause and Effect: Inability to Build Board Consensus

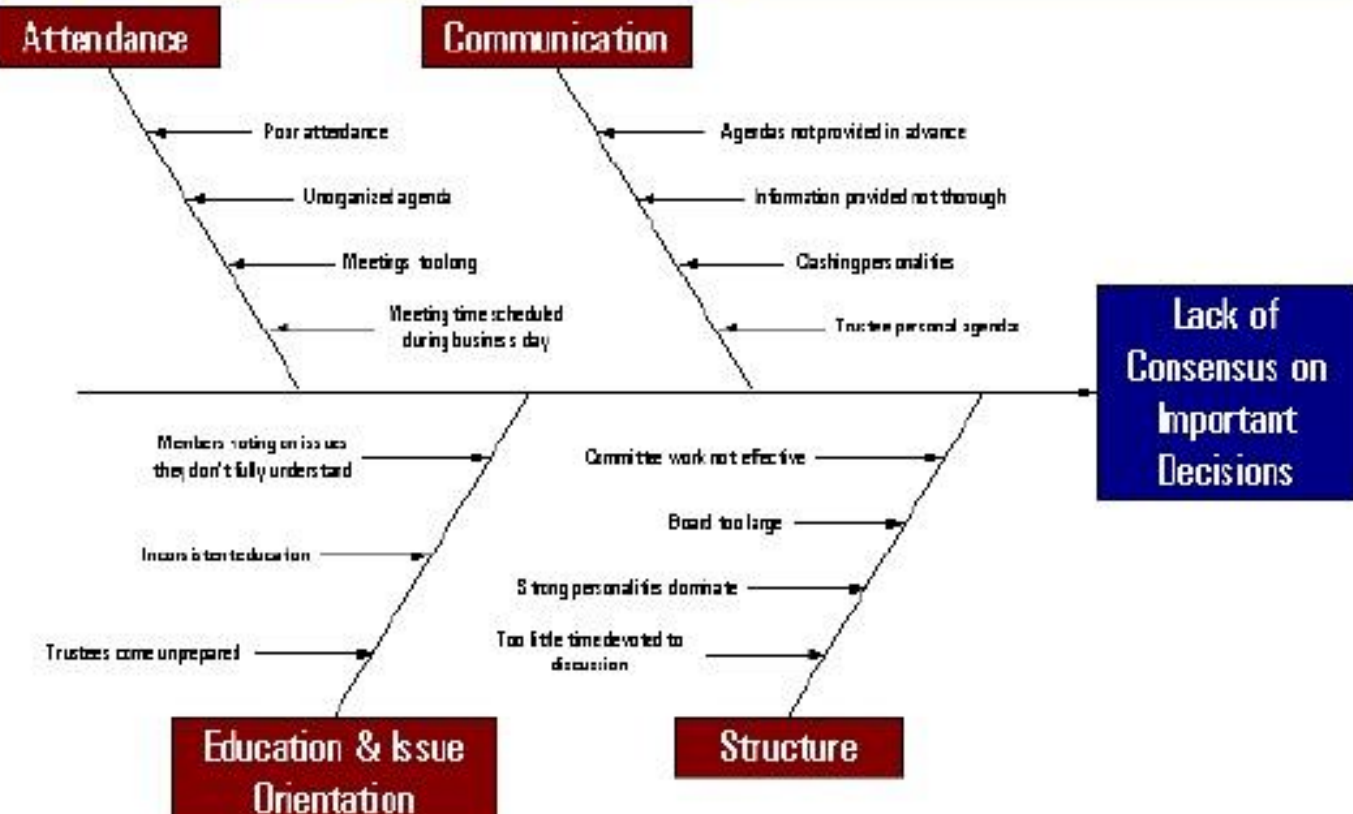

Figure 9: Ishikawa Cause and Effect Diagram (Inability to Build Board Consensus)

Source: The Trustee Toolbox www.mhhp.com

\section{Spider Graph: Overall Self-Assessment Score}

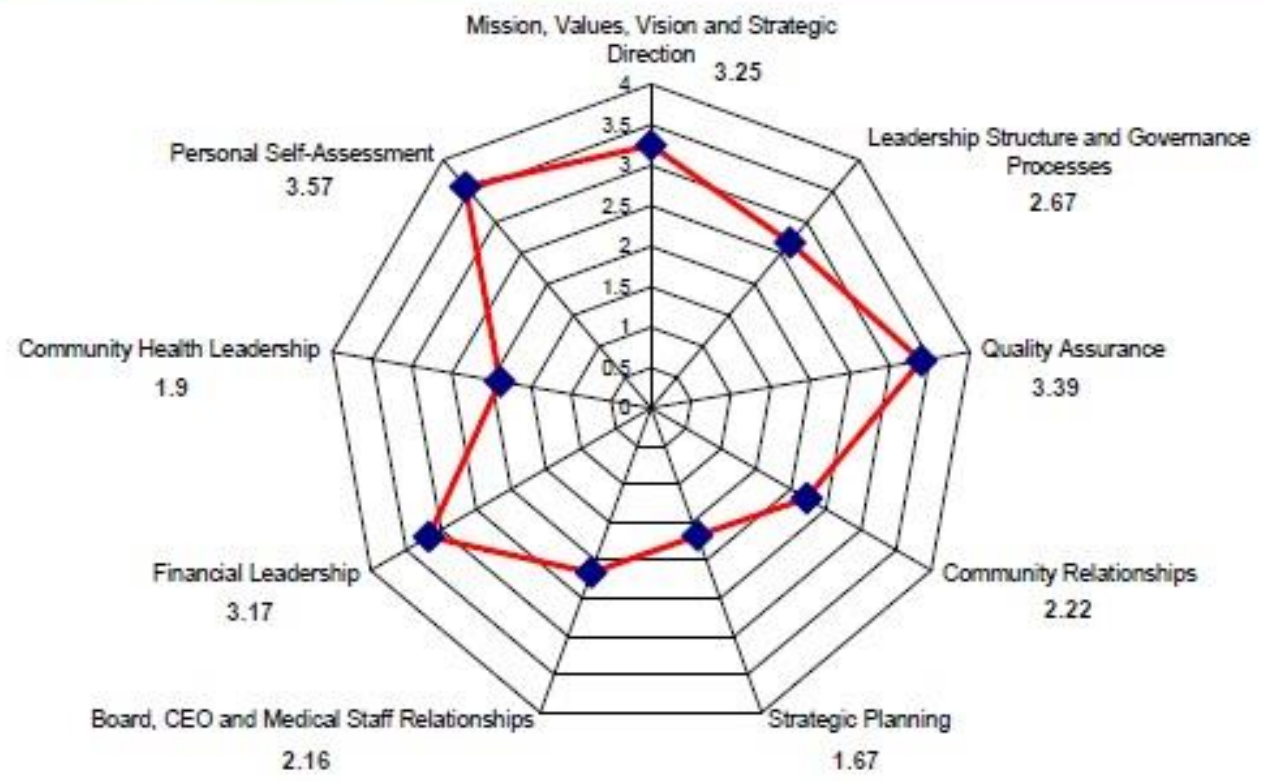

Figure 10: Radar Spider Graph (Board Self-Assessment Score)

Source: The Trustee Toolbox www.mhhp.com

While Diagram 9 exposes possible causes to a problem, Diagram 10 gives a snapshot of leadership attitudes. These are all good but involve a significant time investment on the part of the board. One possible reliable solution and accepted methodology for accessing the current situation can be found in the next section. 


\section{SMMM tool based on the Data Envelopment Methodology as a possible means to evaluate board performance?}

The Balanced Scorecard Institute (www.balancedscorecard.org) created the Strategic Management Maturity Model (SMMM) for busy managers who need a quick assessment of their organization performance. The tool allows to monitor progress in improving maturity of strategic management, and to allow benchmarking across organizations, or departments and in order to identify best practices.

There are 8 slides with 5 options each corresponding to the Eight Dimensions of Strategic Management (Figures 11-18 below for each dimension):

1) Leadership, 2) Culture and values, 3) Strategic thinking and planning, 4) Alignment,

5) Performance measurement, 6) Performance management, 7) Process improvement,

8) Sustainability of strategic management (each slide ranks 1-5 for a maximum total of 8 to 40 points) and the Results are explained in Figures 19-21.

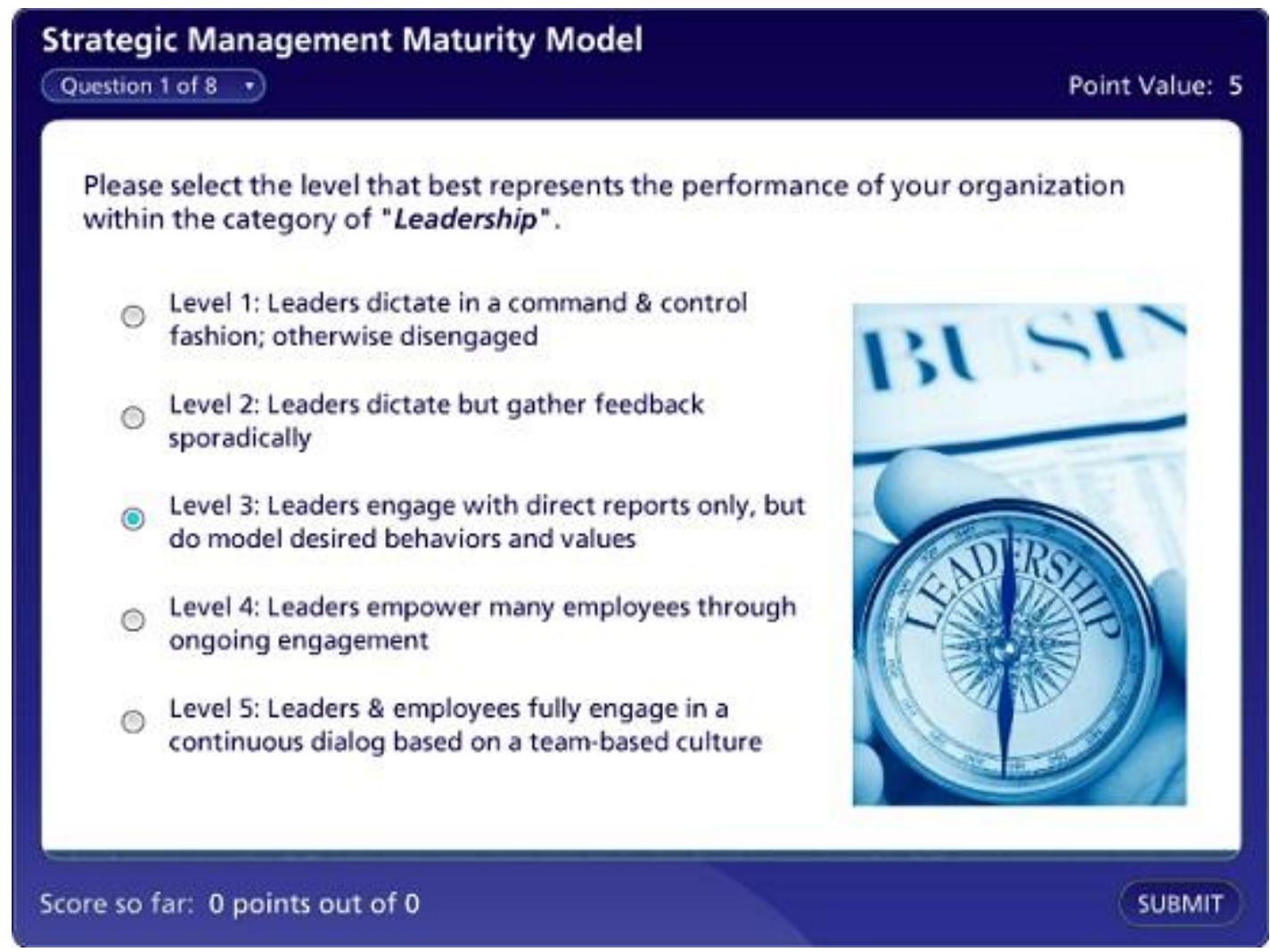

Figure 11: Leadership - Dimension 1 of 8

Source: The Balanced Scorecard Institute (www.balancedscorecard.org) 


\section{Strategic Management Maturity Model}

Please select the level that best represents the performance of your organization within the category of "Values \& Culture".

Level 1: Vision \& values undefined or not shared

Level 2: Vision \& Values published, but not lived

Level 3: Vision \& Values communicated \& understood

Level 4: Vision \& Values collaboratively developed

Level 5: Vision \& Values fully integrated into organization culture

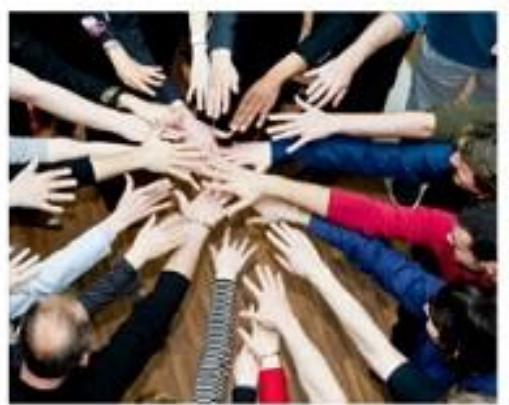

Figure 12: Culture and values - Dimension 2 of 8

Source: The Balanced Scorecard Institute (www.balancedscorecard.org)

\section{Strategic Management Maturity Model}

Please select the level that best represents the performance of your organization within the category of "Strategic Thinking \& Planning".

Level 1: No strategic planning occurs within the organization; no goals defined

Level 2: Strategic planning is the responsibility of a small team and dictated to the organization

Level 3: A structured and open planning process involves people throughout the organization every couple of years

Level 4: Plans are developed and revised regularly by trained, cross-functional planning teams

Level 5: Strategy drives critical organizational decisions

and a continuous improvement planning process is maintained

Figure 13: Strategic thinking and planning - Dimension 3 of 8

Source: The Balanced Scorecard Institute (www.balancedscorecard.org) 


\section{Strategic Management Maturity Model}

Please select the level that best represents the performance of your organization within the category of "Alignment".

Level 1: Work is narrowly focused based on organization structure, with little customer input

Level 2: Customer needs and feedback start to influence more aligned decision making

(- Level 3: Employees know their customers and align strategy to those needs

Level 4: Vision, Customer Needs, Strategy, and

employee reward and recognition systems are cascaded and aligned

Level 5: All structures and systems are aligned with

strategy, and organizational alignment is continuously improved

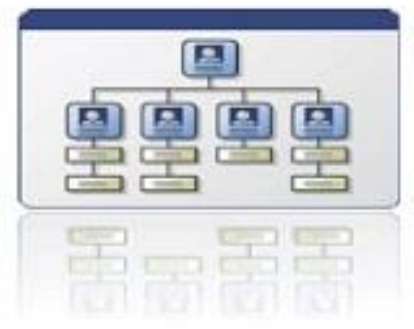

Figure 14: Alignment - Dimension 4 of 8

Source: The Balanced Scorecard Institute (www.balancedscorecard.org)

\section{Strategic Management Maturity Model Question 5 of 8 .}

Please select the level that best represents the performance of your organization within the category of "Performance Measurement".

Level 1: No data, or only ad hoc performance measures are collected

Level 2: Performance data collected routinely, but are mostly operationally focused

- Level 3: Strategic performance measures are collected, covering most strategic objectives

Level 4: Strategic measures are broadly used to

improve focus \& performance and inform budget decisions

Level 5: Measurements comprehensively used and

routinely revised based on continuous improvement

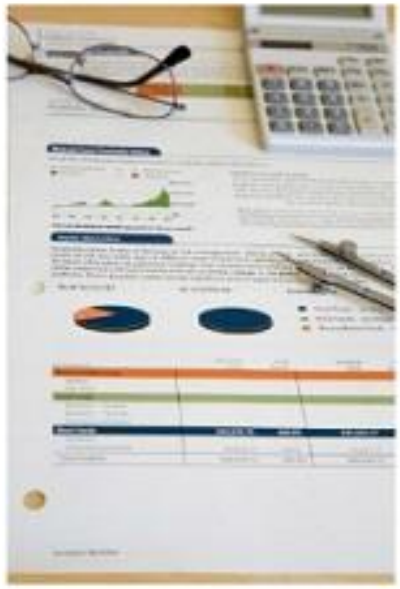

Figure 15: Performance measurement - Dimension 5 of 8

Source: The Balanced Scorecard Institute (www.balancedscorecard.org) 


\section{Strategic Management Maturity Model}

Please select the level that best represents the performance of your organization within the category of "Performance Management".

Level 1: No emphasis on using performance as a criterion to manage the organization

Level 2: Performance reviews required but not taken seriously; no accountability for performance exists

Level 3: Measures are assigned owners and performance is managed at the organizational and employee level

Level 4: Measurement owners are held accountable and performance is managed at all levels

Level 5: Organizational culture is measurement and accountability focused; decisions are evidence-based

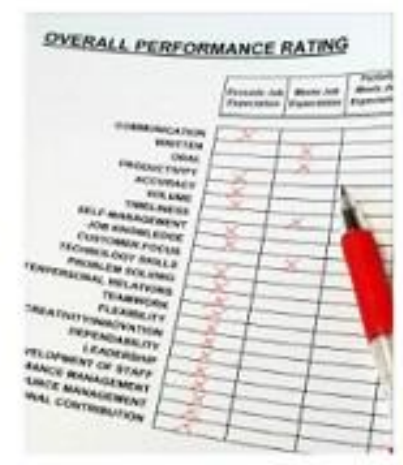

Figure 16: Performance management - Dimension 6 of 8

Source: The Balanced Scorecard Institute (www.balancedscorecard.org)

\section{Strategic Management Maturity Model}

Please select the level that best represents the performance of your organization within the category of "Process Improvement".

Level 1: Processes are undocumented and ad hoc with evident duplication and delays

Level 2: A few key processes documented, and process

improvement models (TQM, Lean Six Sigma, etc.) introduced Level 3: All key processes are identified and documented,

and strategy guides successful process improvement initiative and improvements

Level 4: All key processes are tracked and improved on a

continuous basis and new process improvement ideas are accepted

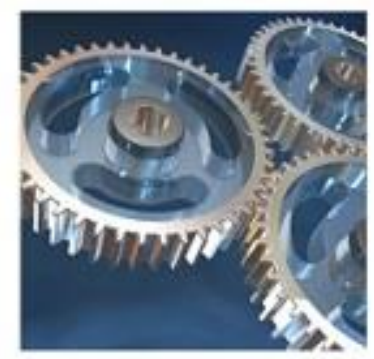

Level 5: Employees are empowered and trained, and a formal process exists for improving process management

Figure 17: Process improvement - Dimension 7 of 8

Source: The Balanced Scorecard Institute (www.balancedscorecard.org) 


\section{Strategic Management Maturity Model

Please select the level that best represents the performance of your organization within the category of "Sustainability".

Level 1: Lack of structure and champions lead to short-term focus on tasks

Level 2: Strategy "champions" identified

Level 3: Formal organization structure in place to maintain focus on strategy

Level 4: Organization has an "Office of Strategy Management " or equivalent.

Level 5: Strategic thinking and management

0 are embedded in the culture of the organization

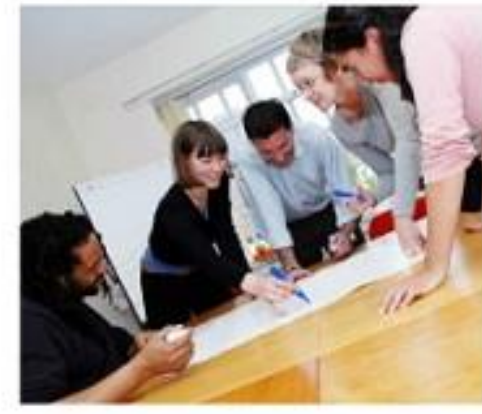

Score so far: 21 points out of 35

Figure 18: Sustainability of strategic management - Dimension 8 of 8

Source: The Balanced Scorecard Institute (www.balancedscorecard.org)

\section{Strategic Management Maturity Model}

\section{Strategic Management Maturity Model}

\section{Your Organization's Strategic Management Maturity Level :}

Your Assessment Survey Score:

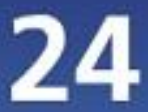

$$
\begin{aligned}
\text { Score of... } \\
8-11=\text { Level } 1 \\
12-19=\text { Level } 2 \\
20-27=\text { Level } 3 \\
28-35=\text { Level } 4 \\
35-40=\text { Level } 5
\end{aligned}
$$

\section{Need More About What Your Maturity Level Means? Select "Read the SMMM Article $\gg$ " Below.}

\section{Thank Youl}

Figure 19: Results - Score

Source: The Balanced Scorecard Institute (www.balancedscorecard.org) 


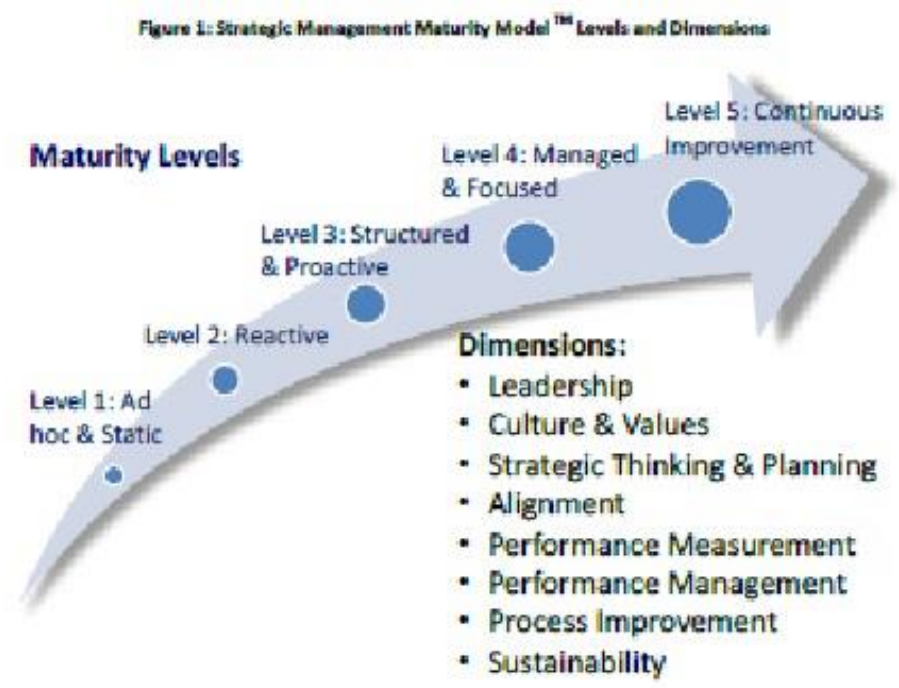

Figure 20: Results - Maturity Levels Graph

Source: The Balanced Scorecard Institute (www.balancedscorecard.org)

\begin{tabular}{|c|c|c|c|c|c|}
\hline & $\begin{array}{c}\text { Level 1: } \\
\text { Ad hoc a Static }\end{array}$ & $\begin{array}{l}\text { Level } 2: \\
\text { Reactlve }\end{array}$ & $\begin{array}{c}\text { Level 3: } \\
\text { structured \& Proactive }\end{array}$ & $\begin{array}{c}\text { Level } 4: \\
\text { Managed \& Focused }\end{array}$ & $\begin{array}{l}\text { Level 5: } \\
\text { Continuous improvement }\end{array}$ \\
\hline Leadership & $\begin{array}{l}\text { Levoers dictatef } \\
\text { command } 8 \text { contro; } \\
\text { othewise disengaged }\end{array}$ & $\begin{array}{l}\text { Leaders dictate but gather } \\
\text { feedoock sporadicaly }\end{array}$ & $\begin{array}{l}\text { Leaders engoge with direct } \\
\text { reports only, but do model } \\
\text { desired behoviors and velues }\end{array}$ & $\begin{array}{l}\text { Leaders empower many } \\
\text { employees trough on going } \\
\text { engagentent }\end{array}$ & $\begin{array}{l}\text { Leaders } 8 \text { employees tally engage } \\
\text { in a continuous dalog based on a } \\
\text { tatr-bused culture }\end{array}$ \\
\hline $\begin{array}{l}\text { Culture } 8 \\
\text { Values }\end{array}$ & $\begin{array}{l}\text { Vision } 8 \text { values undefined } \\
\text { or not shared }\end{array}$ & $\begin{array}{l}\text { Vision \& Values published, } \\
\text { but not lived }\end{array}$ & $\begin{array}{l}\text { Vision \& Walues communicated } \\
\text { \& understood }\end{array}$ & $\begin{array}{l}\text { Vision \& Values colaborativey } \\
\text { developed }\end{array}$ & $\begin{array}{l}\text { Vision \& Values tilly integrated inso } \\
\text { organization cuhure }\end{array}$ \\
\hline $\begin{array}{l}\text { Strategic } \\
\text { Thinking \& } \\
\text { Planning }\end{array}$ & $\begin{array}{l}\text { No strategic planning } \\
\text { occurs within the } \\
\text { organization, no goals. } \\
\text { defined }\end{array}$ & $\begin{array}{l}\text { Strategic planning is the } \\
\text { responsibility of a small } \\
\text { team and dictated to the } \\
\text { organization }\end{array}$ & $\begin{array}{l}\text { A structured and open planning } \\
\text { process involves people } \\
\text { throughoust the organization } \\
\text { every couple of years }\end{array}$ & $\begin{array}{l}\text { Plans are developed and revised } \\
\text { regularly by trained, closs- } \\
\text { functional planning taams }\end{array}$ & $\begin{array}{l}\text { Strategy drives critical } \\
\text { organizational decisions and a } \\
\text { continuous improvemert planning } \\
\text { process is maintained }\end{array}$ \\
\hline Alignment & $\begin{array}{l}\text { Worx is namoanty focused } \\
\text { bosed on organization } \\
\text { structure, with ittle } \\
\text { cusbomer input }\end{array}$ & $\begin{array}{l}\text { Customer needs and } \\
\text { feedback start to influence } \\
\text { more algned decision } \\
\text { making }\end{array}$ & $\begin{array}{l}\text { Employees know their } \\
\text { customer sand align strategy to } \\
\text { those needs }\end{array}$ & $\begin{array}{l}\text { Vision, Customer Needs, } \\
\text { Strategy, and employee reward } \\
\text { and recognition systems are } \\
\text { cascaded and aligned }\end{array}$ & $\begin{array}{l}\text { Au structures and systems are } \\
\text { aligned with strategy, and } \\
\text { organizational alignment is } \\
\text { continuously improved }\end{array}$ \\
\hline $\begin{array}{l}\text { Performance } \\
\text { Measurement }\end{array}$ & $\begin{array}{l}\text { No data, or only ad hoc } \\
\text { performance measures } \\
\text { are collected }\end{array}$ & $\begin{array}{l}\text { Performance data collected } \\
\text { noutinely, Dut are mostly } \\
\text { operationally focused }\end{array}$ & $\begin{array}{l}\text { Strategic performance } \\
\text { measures are collected, } \\
\text { covering most strategic } \\
\text { objectives }\end{array}$ & $\begin{array}{l}\text { Strategic measures are broady } \\
\text { used to improve focus a } \\
\text { performance and inform budget } \\
\text { decisions }\end{array}$ & $\begin{array}{l}\text { Measurements comprehensively } \\
\text { used and routinely revised based } \\
\text { on continuous improvement. }\end{array}$ \\
\hline $\begin{array}{l}\text { Performance } \\
\text { Managernent }\end{array}$ & $\begin{array}{l}\text { No emphasis on using } \\
\text { performance as a criterion } \\
\text { to manage the } \\
\text { Organizaton }\end{array}$ & $\begin{array}{l}\text { Pefformance reviews } \\
\text { required but not taken } \\
\text { seriousty, no accountability } \\
\text { for pelformance exists }\end{array}$ & $\begin{array}{l}\text { Measures are assigned owners } \\
\text { and performance is managed } \\
\text { at the organizational and } \\
\text { employef level }\end{array}$ & $\begin{array}{l}\text { Measurement ouners are heid } \\
\text { accountable and peeformance is } \\
\text { managed at all levels }\end{array}$ & $\begin{array}{l}\text { Organizational culture is } \\
\text { measurement and accountability } \\
\text { tocused; decisions are eviblence- } \\
\text { based. }\end{array}$ \\
\hline $\begin{array}{l}\text { Process } \\
\text { Improvement }\end{array}$ & $\begin{array}{l}\text { Processes are } \\
\text { undocumented and ad } \\
\text { hocwith evident } \\
\text { dupication and delays }\end{array}$ & $\begin{array}{l}\text { A few key processes } \\
\text { oocumented, and process } \\
\text { improvernent models (TOM, } \\
\text { Lean Six sigma, etc) } \\
\text { introduced }\end{array}$ & $\begin{array}{l}\text { All key processes are identified } \\
\text { and documented, and strategy } \\
\text { guibes successful process } \\
\text { improvenent initiative and } \\
\text { improvements }\end{array}$ & $\begin{array}{l}\text { Al key processes are tracked } \\
\text { and improved on a continuous } \\
\text { basis and new process. } \\
\text { improvementideas are accepted }\end{array}$ & $\begin{array}{l}\text { Employees are empowered and } \\
\text { trained, and a formal proce ss exists } \\
\text { for improving process management }\end{array}$ \\
\hline Sustaina billity & $\begin{array}{l}\text { Lack of structure and } \\
\text { champions lead to short- } \\
\text { term focus on tagks }\end{array}$ & $\begin{array}{l}\text { Strategy thampions" } \\
\text { identified }\end{array}$ & $\begin{array}{l}\text { Formal onganization stuchure } \\
\text { in place to maintain focus on } \\
\text { strategy }\end{array}$ & $\begin{array}{l}\text { Organization has an "Office of } \\
\text { Strategy Management" or } \\
\text { equivalent. }\end{array}$ & $\begin{array}{l}\text { Stralegicthinking and munagement } \\
\text { are embedded in the culture of the } \\
\text { organization }\end{array}$ \\
\hline
\end{tabular}

Figure 21: Results - Maturity Levels Explained

Source: The Balanced Scorecard Institute (www.balancedscorecard.org)

\section{Conclusion}

Recent national reports from Australia, Scotland and the United States have examined how external mechanisms for performance measurement contribute to internal development and public accountability. The common conclusions are that:

1) Voluntary and statutory agencies should be actively coordinated for consistency and reciprocity. 
2) Consumers should be prominently involved.

3) National programs should be comparable internationally.

4) The standards, processes and results of external assessments should be transparent and freely accessible to the public.

The Greek economic crisis exposes needs and priorities that should be exploited in the future.

The experience and performance of social Solidarity hospitals across Europe and Greece should help create better value for money hospitals. The authors believe that the future health systems across Europe should be socially just and inclusive. This will require that the system becomes more patient friendly and that Hospital Boards performance should be often monitored with audits and evaluated with tools like the SMMM Tool, to ensure financial and health value performance for the money invested. Hence Hospital CEOs / should by preference be a good administrator with extensive Business Management Experience while caring for the Health mission of generations of patients.

\section{Bibliography}

Chen C.M. \& Delmas, M. (2010) Measuring Corporate Social Performance: An Efficiency Perspective. UCLA

Miller, P. (Southern Cross University) (2009) Board performance evaluation: case study of a private hospital in Australia. Review of International Comparative Management. 10(1), 140.

The European Observatory on Health Systems (2009) Investing in hospitals of the future, WHO

The Social and Cultural Planning Office (2004) Public Sector Performance, An international comparison of education, health care, law and order and public administration. The Hague, September 2004

Uwe E. Reinhardt U.E. (2010) The Economics of For-Profit and Not-For-Profit Hospitals, Nonprofit hospitals owe society community benefits in exchange for their tax exemption, but what is a fair amount? Health Affairs. 19(6), pp56-82

\section{Websites}

American Governance Web site, https://www.americangovernance.com/checklist (accessed 17 February 2016)

England.nhs,2014, 'Friends and Family Test: Capturing Patient Feedback', https://www.england.nhs.uk/ourwork/pe/fft/fft-comms-res/ (accessed 28 March 2016)

The Social Solidarity clinic of Peristeri 2015, (in greek), https://iatreioallperisteriou.wordpress.com/news-in-english/ (accessed 20 March 2016)

The Social Solidarity clinic of Helliniko, 2015, (in greek), www.mkiellinikou.org (accessed 20 March 2016)

Trustee Toolbox www.mhhp.com (accessed 12 March 2016)

The Balanced Scorecard Institute, 2010, ' the Strategic Management Maturity Model (SMMM)', www.balancedscorecard.org (accessed 10 April 2016) 